\title{
Re-territorializing Empire: Imperial Memories and Contested History in Forte Ardietti
}

\section{Giulia Carabelli}

In the summer of 2017, I attended Opera Sesta, an annual historical re-enactment event in Ponti sul Mincio near Lake Garda, in the north of Italy. In this chapter, I present a set of photographs taken on site and extracts of interviews with re-enactors to explore the meanings of "living history" and the implications of reinhabiting the contested memories of the Austrian Empire. Overall, this chapter explores the ways in which reinhabiting history produces a space conducive to the renegotiation of local identities that are more capacious and able to accommodate - if not resolve - the contested legacies of imperial and anti-imperial struggles that so thoroughly forged the history of this place. The visual essay presented along with the chapter shows how Opera Sesta alters the landscape by re-setting history to the nineteenth century. These photographs were selected to provide a sense of what the fort looked like but also to evoke the atmosphere of the event as I experienced it. The text is not explicative of the images but rather a compendium to them. The images remain untitled to encourage and invite readers to produce their own associative stories. 


\section{Preamble}

Ponti sul Mincio is a small town of 2,400 inhabitants. Here, between 1856 and 1861, the Habsburgs built Werk VI (Opera Sesta, in Italian). This fortress, also known as Forte Ardietti, was part of a series of sixteen, all built from 1815 onwards in the northeast of Italy between the cities of Peschiera del Garda, Mantova, Legnago and Verona (Rolf 2011; Weiss 2006). This defence system, remembered as the Quadrilatero (the Quadrilateral), was an armed fortress that formed a bastion against the forces of the Italian unification movement (Risorgimento). In fact, the construction of Forte Ardietti was halted (and then restarted) in 1859 , during the second of three wars that would eventually free these territories from imperial control. After achieving independence, Forte Ardietti remained a military zone and operated as an ammunition depot until recently. It was only in 2014 that the municipality of Ponti sul Mincio gained full control of the site, opened it to the public and agreed to allow the Associazione Cultura e Rievocazione Imperi (a cultural association for the valorization of local history) to establish their headquarters there. Opera Sesta, which started in 2015, is their major annual event, whose goal is to re-enact the key events of the Risorgimento. The organization requires "commitment and sweat", I was told, but "it's totally worth it".

\section{Opera Sesta}

In 2017, Opera Sesta focused on the Battle of Solferino (1859) - fought between the Franco-Piedmont-Sardinian alliance and the Austrian Empire during the second war of independence. Famously commemorated at the beginning of Roth's Radetzky March (2002[1932]), the battle ended with the defeat of the Habsburgs and was crucial to advance the Italian unification 
project. Even though statistical data is not available, I can attest that the event was very well attended. There were families with young children, groups of friends, and curious visitors of all ages. Some came for the guided tours of the fortress, others for the evening concerts and balls or to join one of the many workshops on offer, such as nineteenth-century dance classes or sword training. During my time there, the atmosphere was charged with electric excitement. The sound of the battles outside the walls and duels inside shattered the warm summer air, sending shudders of excitement down the spines of all not in costume. On the second day, after a particularly tense armed confrontation, an injured soldier was brought to the medical room, where a surgeon attempted to save his life in front of a stunned and silent crowd. A young girl, towering over everyone from her father's shoulders, screamed, "Mummy! Will he survive?" In that moment, I suddenly realized that I too was watching impatiently to learn whether the poor soldier on the operating table would survive - the performance was entirely immersive. I was also impressed by the stoicism of the women wearing big gowns and soldiers in heavy uniforms despite the scorching temperature; the bar arranged inside the fortress offered the only respite from the unrelenting sun, and here I met several re-enactors taking breaks. There were Italian associations of re-enactors as well as groups from Czechia and Austria. I interviewed only Italian re-enactors because I wanted to understand their motivation to relive the key moments that led to the unification of Italy. Accordingly, I asked several questions about how they became involved in historical re-enactment, as well as their motivations for attending this specific event.

All my interlocutors became re-enactors because of their passion for history. In their words, this was strongly connected to the need to learn more about their roots - some had distant relatives who had fought for Italian independence, while others saw their 
participation as a celebration of their family heritage, which had roots in the local area. Many said that this historical period fascinates them because it was crucial for the building of Italy as a united nation state. For the sheer love of re-enacting the Risorgimento, they learnt new languages (such as German or French), travelled extensively to read archives, studied military treaties, and visited museums and collections to re-create costumes and accessories. Re-enactment, they all agreed, is a lifetime commitment - beyond being a very expensive hobby - so much so that it often impacts on the choice of partners and friends. The goal of each re-enactor is to reinhabit history in a way that is as close as possible to the original. In this sense, all my interlocutors aspired to know more about how the historical events they re-enact really felt, looked and sounded. Many remarked that their mission is educational; they want people to become "curious" about their past and to appreciate the value of their "territory". The organizers, in particular, embraced the hardship of setting up this event to share their acquired historical knowledge and educate people in a way that is also playful and exciting. What matters to them is that, by "living history", they add value to territory because they expose its uniqueness. Further, to reinhabit history reinforces existing emotional bonds with territory in a manner that strongly determines personal and group identities.

\section{Territory}

The importance of "territory" - knowing it, appreciating it, discovering it - was strongly emphasized during the interviews I conducted. The local councillor for tourism, Elisa Turcato, explained how tourism had been steadily growing for years in Ponti. At the beginning, people came to visit the medieval castle, but more recently they have been mainly attracted by events at Forte Ardietti. She said that what is important to her, as the person responsible 
for developing the tourism sector, is to implement plans that celebrate their local territory. And this is exactly what Opera Sesta does by supporting the wider process of community learning, or rediscovery, of the history of this territory. As Leonardo Danieli, president of the association behind Opera Sesta, emphasized,

We are interested in the 19th century and what remains of the Austrian empire here, physically, but also in the culture of the place because that history made our territory even if we don't see traces anymore or we don't remember what happened then.

Territory, as Elden (2010) reminds us, is never simply a neutral space. Or, as Bertelsen and Murphie (2010) put it, territory is always existential because it allows movements and yet keeps everything in place. Territories are themselves "political technologies", or a series of techniques, signifiers and abstract concepts that control and organize space. Being neither "land/landscape" nor even "terrain", territory is composed of a bundle of practices that give affective resonance to a specific place and time. At Opera Sesta, history itself - or the act of remembering history as a means of (re)producing one's subjective identity - becomes the raw material through which this territory acquires its meaning and value, both cultural and economic.

\section{Opera Sesta as Territory}

To the uninformed traveller, Forte Ardietti is just a well-preserved military fortress immersed in the green fields of Ponti sul Mincio. Seen from above, the entire space harmonizes with the surrounding landscape, becoming integral to it. In the series of photographs that form part of this chapter, I attempted to capture the ways in which the Opera Sesta re-territorializes the landscape to transform it radically, giving it a new identity. There 
are weapons, tents, uniforms and attires styled to the fashion of the nineteenth century. These are the signs of human life that emerges from Forte Ardietti as it is reinhabited and dramatically transformed over the span of a weekend.

Locating the headquarters of the Associazione Imperi in the fortress was the first step in the process of reclaiming this space and its history. But what the actual re-enactment does is not simply teach the "history of the territory". Opera Sesta brings this territory to life, by occupying its space and making it anew. Yet this creation is not intended to bring forth a new place and time but a re-creation of a place and time long passed, yet always latently present within this fortress. Opera Sesta is surely a celebratory event that gathers the local community - heavily involved in the setting up and execution of the project - as well as an opportunity to gain additional revenue for the town's tourism sector. But Opera Sesta, for its more passionate participants, offers the unique opportunity to reinhabit the past in order to make the present more comprehensible. Opera Sesta is, in this sense, educational beyond its role of explaining history. For instance, all of the members of the Associazione Imperi I interviewed stressed the importance of knowing why German words remain in the local dialect, as well as certain ways of saying things. They are proud of being recognized as the heirs - if you like - of a history that intersected with the Austrian Empire. And yet, at Opera Sesta, there were no anti-Italian sentiments that I could sense, nor attachments to Austrian-ness. All considered, Opera Sesta is about the Risorgimento and the history that led to the unification of Italy. However, the local re-enactment group plays the part of the Austrians. Their uniforms are characteristically blue and their commands are in German. They hold tribunals for treason and execute spies and enemies of the empire. One of these soldiers confessed: 
It's hard to always be the bad guys ... of course here everyone cheers for the Italians ... we are in Italy ... but if I were born at that time, I would not be Italian, I would be part of the empire so ... I don't choose to be who I am here, I am who I would have been if we turned back in history. There is nothing political about this.

As Hayes (2016: 1202) explains, "performing historical events produces knowledge about time" but it also enables the "emblematizing of place". During Opera Sesta, Forte Ardietti becomes the emblem of a history negated and a history reclaimed. Crucial to this re-enactment event is not the celebration of empire but rather the re-enabling of the battles that destroyed it. And, yet, Opera Sesta is not about the celebration of Risorgimento either. What this historical re-enactment does is to amplify the moments in between empire and Italy when the boundaries of this area were transformed. By inhabiting this transitional history, Opera Sesta reclaims the existence of another territory - one that exists despite and because of history. It is the territory that holds the potential for a different identity to exist, one that is hybrid and without the need to choose between imperialism and nationalism. As Crang and Travlou (2001: 161) write, space and time relate through memory in the pursuit of spatialization: "the spatiality of memory links the social and the personal". In Forte Ardietti, empire is resurrected not to reclaim territory for the empire. Rather, Opera Sesta becomes the means to rediscover and reappropriate the traces that make this area Italian, yet whose past is so different from the rest of Italy. In this sense, to reclaim this territory means to reclaim a different identity. Surely, this process speaks volumes about the complexities of Italian national identities.

Crang and Tolia-Kelly (2010: 2316) propose to look at heritage sites as "occasions for doing and feeling of connecting representations and thoughts". They see these sites as "enablers in 
the traffic between places, things, identities and belongings" (Ibid.). In the same spirit, this chapter has offered a panoramic view of Forte Ardietti during Opera Sesta to document the process of remaking its territory at a crucial moment in time, when the flow of history has been paused in order to make way for old stories and the creation of new identities.

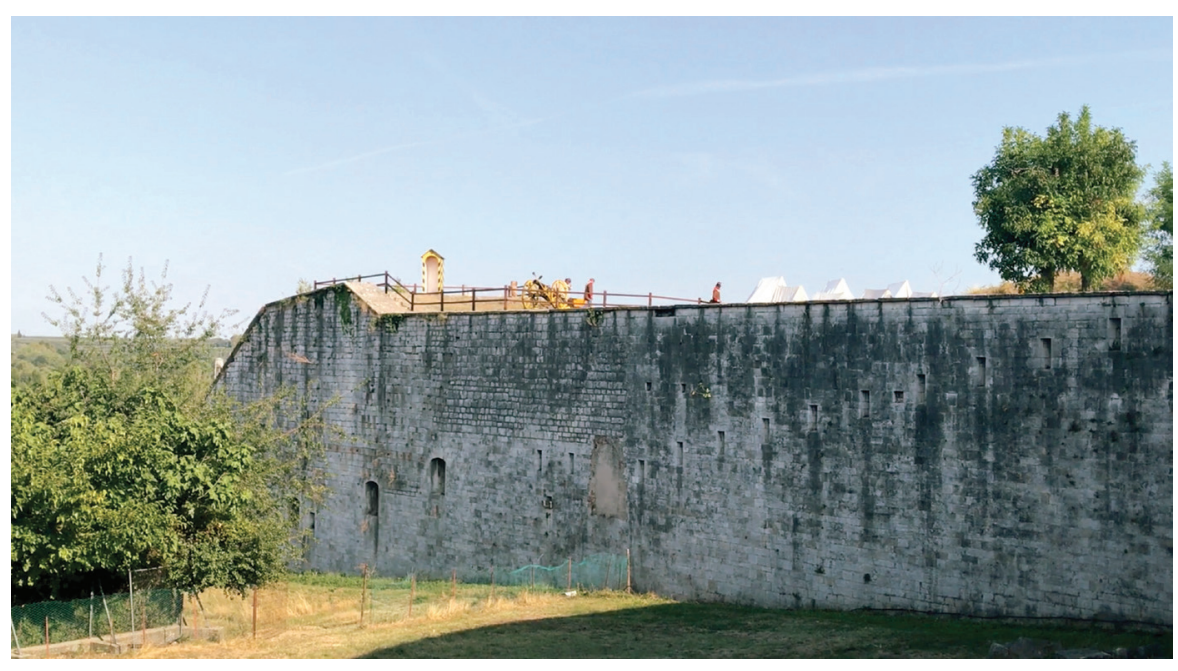

Figure 1. 


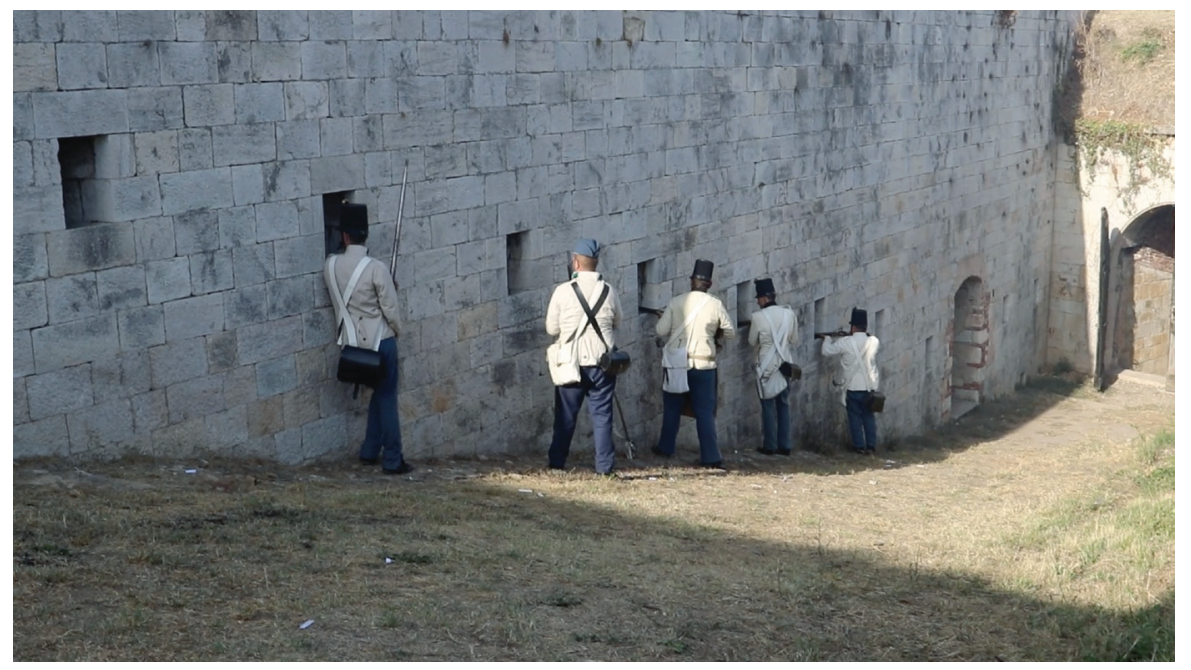

Figure 2. 


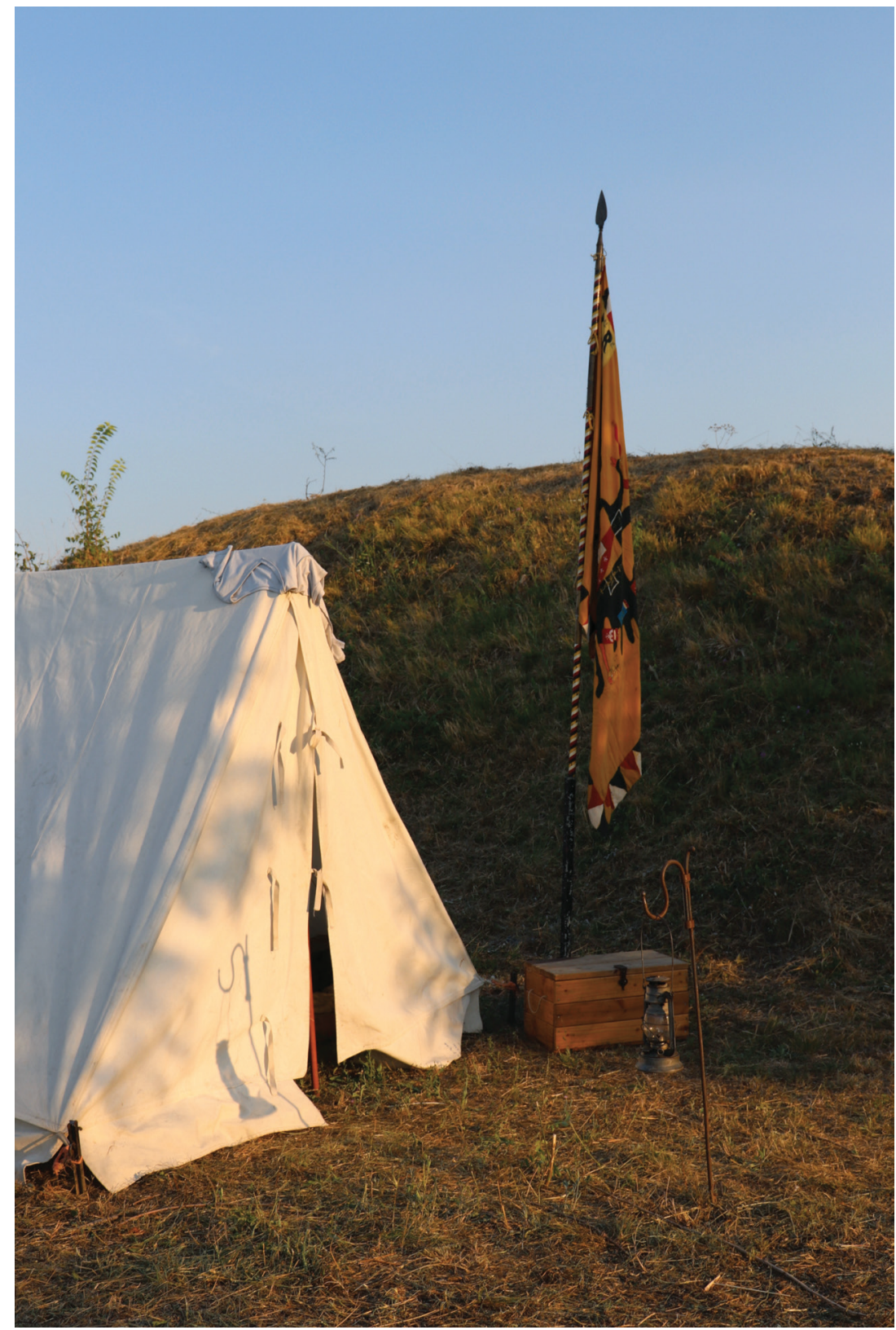

Figure 3. 


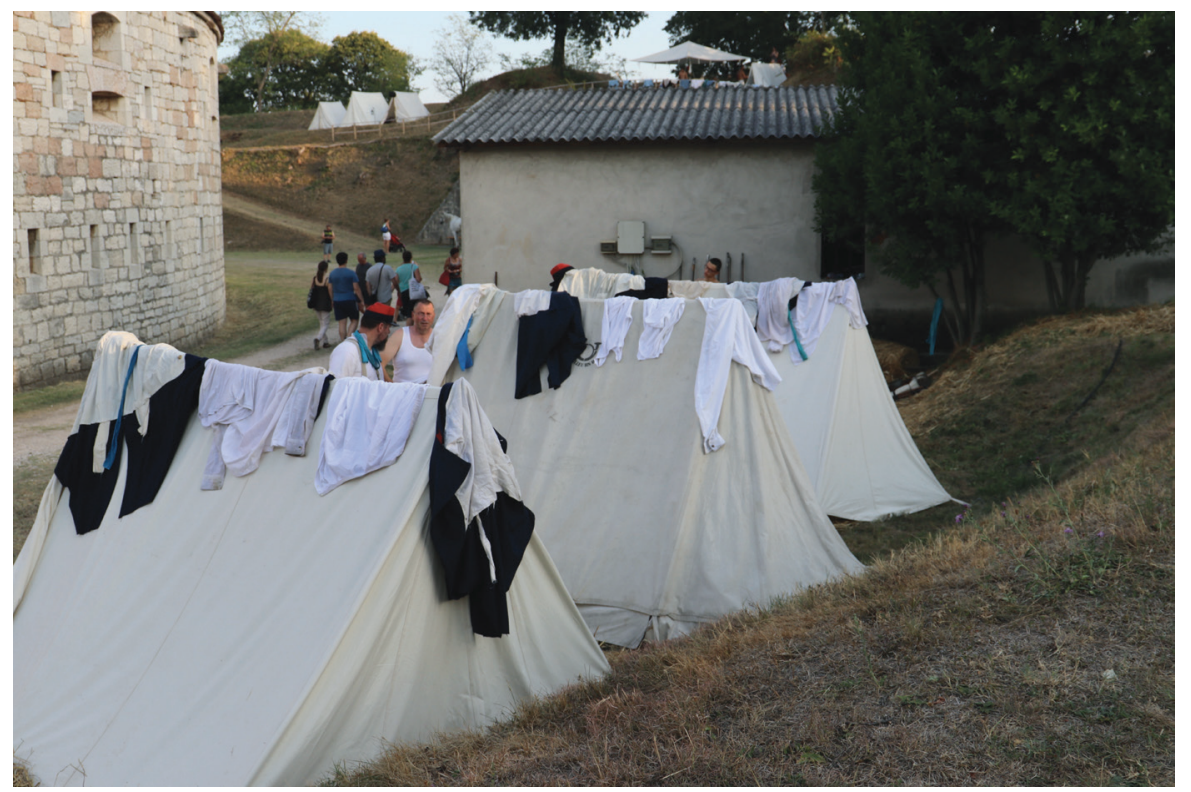

Figure 4. 


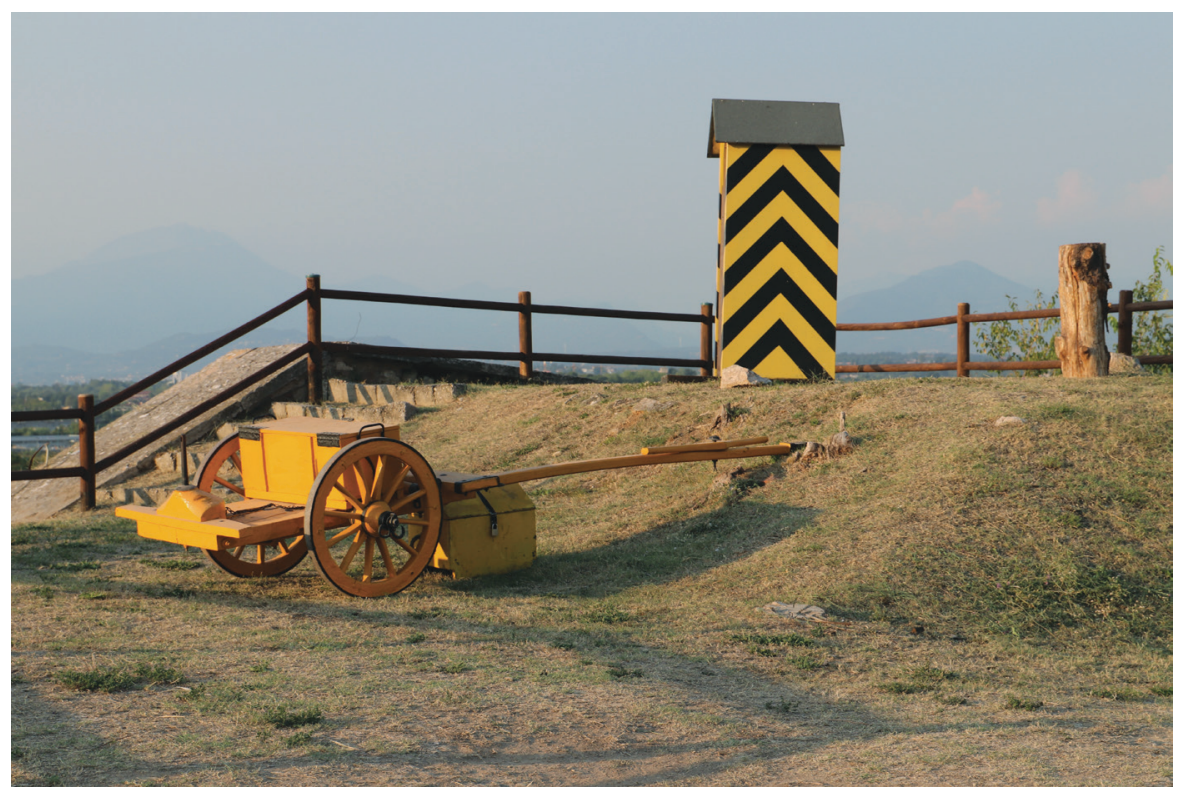

Figure 5. 


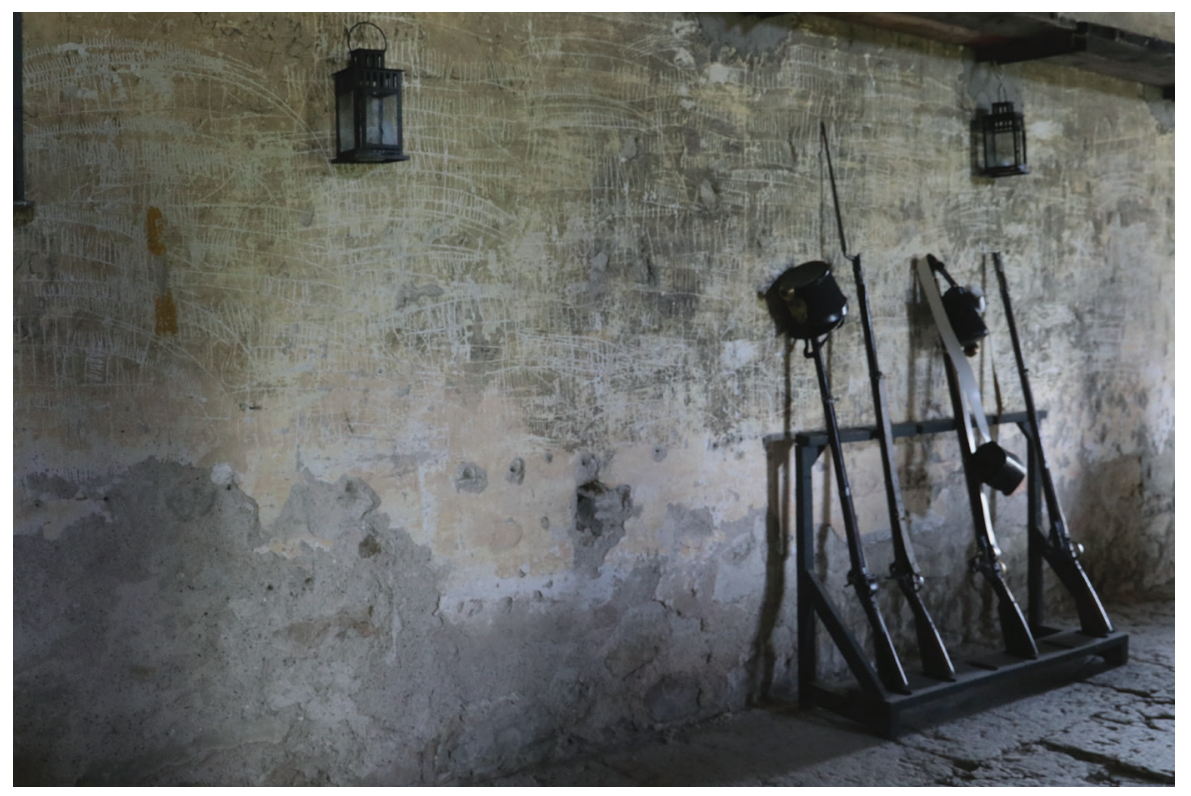

Figure 6. 


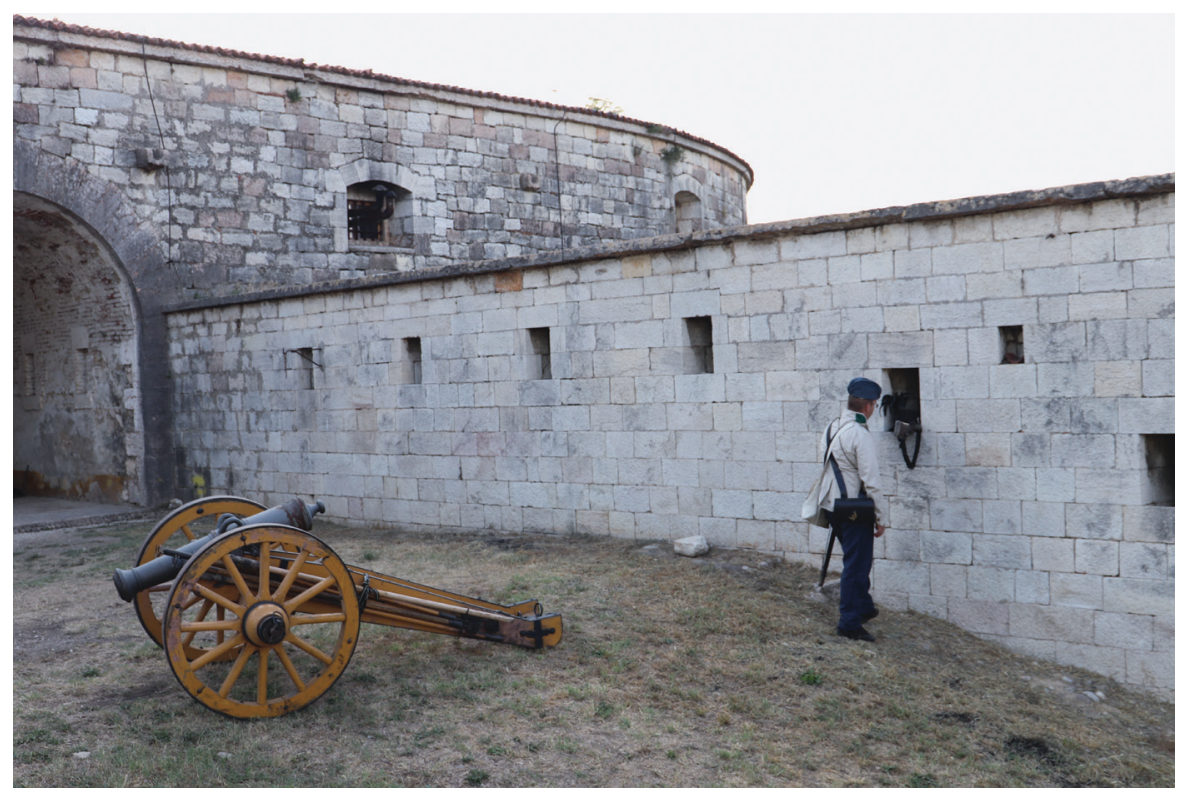

Figure 7. 


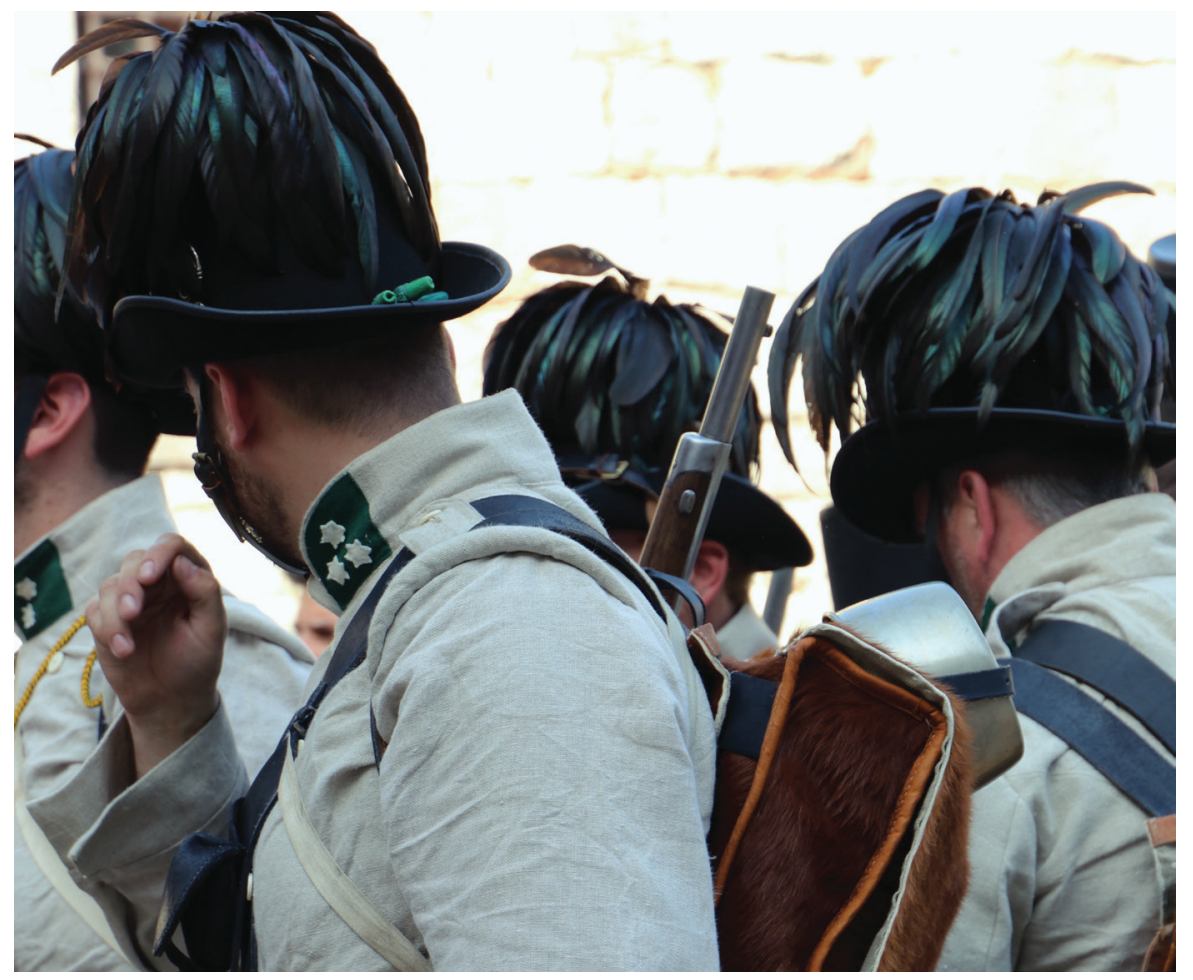

Figure 8. 


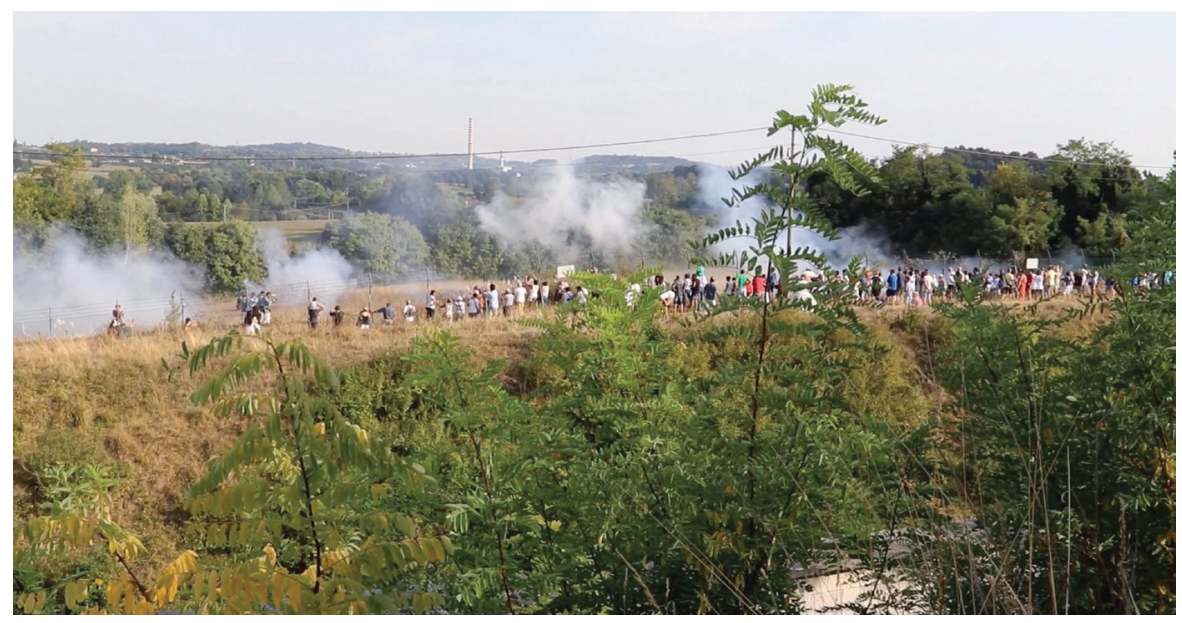

Figure 9. 


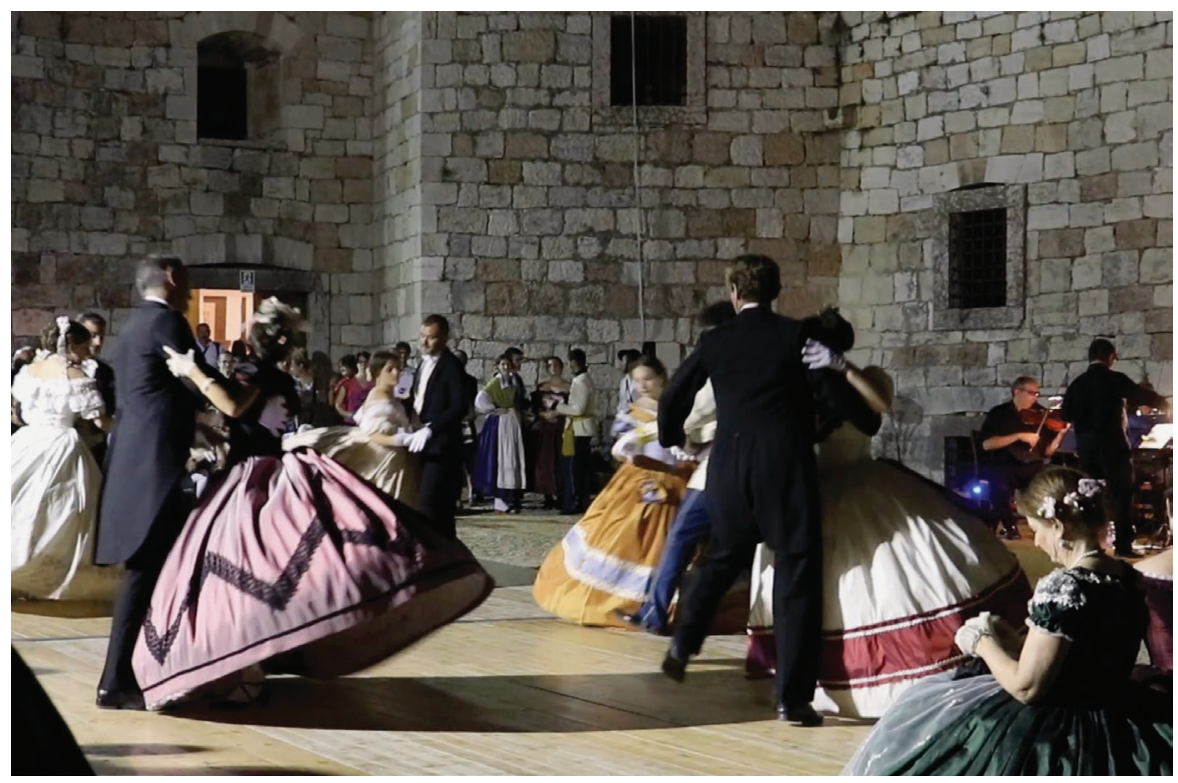

Figure 10. 
GIULIA CARABELLI (Queen's University Belfast) is a lecturer in sociology. She was a member of the 'Empires of Memory' research group at the Max Planck Institute for the Study of Religious and Ethnic Diversity from 2016 to 2019. She can be reached at G.Carabelli@qub.ac.uk

\section{References}

Bertelsen, Lone and Andrew Murphie. 2010. "An ethics of everyday infinities and powers. Felix Guattari on Affect and the Refrain". In: Gregg, M. and Seigworth, G.J. (eds) The Affect Theory Reader. Durham, NC, and London, Duke University Press, pp. 138-157. Mike Crang and Penny S. Travlou. 2001. "The city and topologies of memory". Environment and Planning D: Society and Space 19: 161-177.

Crang, Mike and Divya Tolia-Kelly. 2010. "Nation, race, and affect: senses and sensibilities at national heritage sites". Environment and Planning A: Economy and Space 42 (10): 2315-2331.

Elden, Stuart. 2010. "Land, terrain, territory”. Progress in Human Geography 34 (6): 799-817.

Hayes, Janys. 2016. "Sites to remember: Performing the landscape in cultural history". Journal of Literature and Art Studies 6 (10): 1194-1203.

Rolf, Rudi. 2011. Festungsbauten der Monarchie : die k.k.- und k.u.k.-Befestigungen von Napoleon bis Petit Trianon, eine typologische Studie, Middelburg, PRAK Publ.

Roth, Joseph. 2002 [1932]. The Radetzky March. London, Granta Books.

Weiss, Ulrike. 2006. Österreichische und italienische Festungsbauten östlich des Gardasees 1849 - 1907. Graz, Vehling. 